\title{
ANALISIS SEMIOTIK MEME ANIES BASWEDAN BANJIR JAKARTA
}

\section{Ali Imron Hamid, M.I.Kom}

\author{
Email : ali iham@yahoo.com
}

Universitas Bina Sarana Informatika

\begin{abstract}
ABSTRAK
Maraknya penggunaan media sosial di Indonesia, membuat para penggunanya bebas memproduksi berbagai pesan komunikasi berdasarkan fenomena yang ada. Konsekuensi ini lantas menghadirkan kreativitas warganet dalam memproduksi meme berupa gambar atau video yang berisi gagasan, ide, yang lucu sebagai sarana hiburan. Namun belakangan meme yang tadinya hanya dimaksudkan untuk bahan candaan memiliki tujuan lain yaitu satire untuk menyudutkan pihak-pihak tertentu seperti pada peristiwa banjir Jakarta yang melahirkan meme-meme yang beragam untuk mengkritik Gubernur Jakarta Anies Bawesdan. Penelitian bertujuan untuk mengungkap makna semiotika di balik meme Anies Bawesdan tentang banjir Jakarta di twitter. Metode penelitian ini menggunakan pisau analisis semiotika Charles Pierce berupa tanda, obyek dan penafsir. Hasil penelitian mengungkap ada hubungan dan kesesuaian antara tanda dengan makna semotika. Warganet ramai-ramai menggunakan gambar sebagai tanda untuk mengungkap ekspresi ketidaksukaan terhadap respon Anies Bawesdan dalam menuntaskan banjir Jakarta. Sedangkan makna obyek dalam meme terebut merupakan sindiran atau nyinyiran atas kelambanan Anies dalam menyelesaikan masalah banjir.Sedangkan daari sisi penafsir ada kesesuaian pemikiran dari warganet dengan meme hasil buatannya yang menyimpulkann bahwa Anies tidak becus menuntaskan masalah banjir Jakarta.
\end{abstract}

Kata Kunci: meme, media sosial, semiotik, Anies Bawesdan.

\begin{abstract}
The rise of the use of social media in Indonesia makes its users free to produce various communication messages based on existing phenomena. This consequence then presents the creativity of citizens in producing memes in the form of pictures or videos that contain funny ideas as entertainment facilities. But lately, memes that were only intended for jokes had another purpose, namely satire to pressure certain parties in Jakarta flood that produced various memes to criticize Jakarta Governor Anies Bawesdan. The research aims to uncover the meaning of semiotics behind Anies Bawesdan's meme about the Jakarta flood on Twitter. This research method uses Charles Pierce's semiotic analysis knife in the form of signs, objects and, interpreters. The results of the research revealed that there was a relationship between the signs and the meaning of semiotics. Netizens were busy using pictures as a sign to express the expression of dislike for Anies Bawesdan's response to the flooding of Jakarta. While the meaning of the object in the meme is a satire or sign of Anies's inaction in solving the problem of flooding. While from the side of the interpreter there is a congruence of thought of the netizen with the result of the artificial meme which concludes that Anies is incapable of solving the Jakarta flood problem.
\end{abstract}

Keywords : meme, social media, semiotic, Anies Bawesdan

36 | http://ejournal.unis.ac.id/index.php/DK/index 


\section{PENDAHULUAN}

Pengguna internet di Indonesia pada tahun 2019 tercatat mengalami peningkatan bila dibandingkan dengan tahun 2018 lalu. Data Asosiasi Penyelenggara Jasa Internet Indonesia (APJII) menyebutkan bahwa pengguna internet di Indonesia saat ini mencapai 171,17 juta jiwa atau sekitar 64,8 persen dari total penduduk Indonesia yang mencapai 264 juta jiwa. Jumlah tersebut mengalami kenaikan bila dibandingkan dengan tahun 2017 dengan 54,86 persen pengguuna internet di Indonesia. Secara keseluruhan pertumbuhan pengguna internet di tahun 2019 adalah 10,12 persen.

Sementara berdassarkan data Indonesia Digital 2019 menyebutkan bahwa pengguna media sosial di Indonesia pada tahun 2019 tercatat 150 juta jiwa pengguna. Dari data tersebut sebanyak 130 juta jiwa adalah pengguna facebook, 6,43 juta jiwa adalah pengguna twitter, 62 juta jiwa adalah pengguna instagram, 12 juta jiwa adalah pengguna linkedn. Tak ayal dengan tingginya pemanfaatan internet dan media sosial memunculkan fenomena baru di kalangan warganet dalam membuat meme di media sosial.

Meme tersebut berupa ide, perilaku, gagasan yang dituangkan dalam bentuk gambar disertai dengan komen-komen yang menyentil untuk membangkitkan rasa humor kepada para penerimanya di media sosial. Meme diproduksi berdasarkan fonemena atau topic yang lagi hangat dengan mengambil berbagai bahan seperti berita, kutipan narasumber, video, dan hyperlink. Setelah diproduksi meme kemudian disebarluaskan di media sosial hingga menimbulkan efek viral. Kepopuleran meme di media sosia ini karena mengandung konten humor yang satire yang menyindir karena berisi curahan ekspresi atau perasaaan penggunanya di dunia maya. (Luthfi, 2015).

Meme berasal dari bahasa Yunani kuno mimeme yang berarti sesuatu yang meniru atau menyerupai. Istilah meme ini pertamakali dicetuskan oleh pakar genetika Richard Dawkins pada tahun 1976 melalui bukunya yang berjudul "The Selfish Gene" . Dalam perkembangannya mimeme kemudian disinngkat menjadi meme seperti kata gen. Dawkins menganggap bahwa meme itu adalah sesuatu yang meloncatloncat di dalam kepala kemudian menyebar seperti virus. (Brodie, 2005). Pada masa awal, meme digunakan untuk menjelaskan teori evolusi budaya yang bertransformasi dari ide, pemikiran, gagasan, kebiasaan, lagu atau fashion sebagai contoh-contoh kebudayaan manusia. Dawkins menganalogikan meme seperti gen yang dapat berpindah dari tubuh ke tubuh lewat sperma dan sel telur sehingga perkembangbiakannya berlangsung sangat cepat. Gen itulah yang kemudian melakukan imitasi karakter dan sikap saat menempel pada tubuh. Disinilah awal proses penciptaan kebudayaan manusia yang terus berlangsung sampai saat ini.

Karena itu, seperti selayaknya gen, meme mampu mereplika dirinya sendiri, dan berevolusi dalam ranah kebudayaan. Pada perkembangannya kemudian, meme kemudian dipahami sebagai hasil dari produk gambar, foto atau video dengan konten-konten yang berisi pemikiran dari si kreatornya itu sendiri. Setelah proses penciptaan dilakukan maka oleh sang creator disebarluaskan di berbagai platform media sosial termasuk twitter. Seiring waktu, meme pun berevolusi lewat penciptaan meme-meme baru dengan topik atau fenomena yang sedang hangat. Meme yang lama pun akan tergantikan dengan 
meme baru yang lebih segar dan update. Proses evolusi meme di internet ini terjadi sangat cepat mengikuti apa yang sedanng popular saat itu. (Alimecca, 2014).

Sebagai produk budaya, meme adalah fenomena baru yang disebarluaskan dan menjadi viral secara cepat. Penyebaran yang viral itu sangat terbantu dengan teknologi internet yang memungkina masing-masing pengguna saling terhubung di dunia maya. Hal ini pula yang melahirkan istilah baru yaitu meme internet sebagai produk budaya siber yang menonjolkan sisi visual berupa gambar (Pusanti dan Haryanto, 2015) dan kata-kata yang menyentil. .

Kehadiran meme di Indonesia menjadi fenomena sosial sebagai akibat dari konsekuensi kebebasan demokrasi dan berekspresi melalui media. Keberadaan media sosial yang sangat marak ikut membuaat meme tumbuh subur dalam berbagai percakapan di lini massa media sosial. Tidak jarang pula, warganet menggunakan meme sebagai alat komunikasi atau menciptakan opini di media sosial. Meme-meme yang diproduksi tersebut seringkali memuat konten-konten sindiran berupa foto ataupun narasi yang lucu dan cenderung satir. Bahkan tidak sedikut pula para kreatornya membuaat parody perilaku dari aktor-aktor di media sosial maupun aktor politik sebagai subyek kreasi memenya. Sehingga dari situlah proses penciptaan meme dilakukan yang digunakan para kreatornya untuk menyampaikan kritik melalui meme. Sebagai produk budaya popular meme telah menjungkirbalikan logika melalui pencitptaan di luar nalar alias batas normatifnya. Terkadang meme yang ditampilkan pun seringkali luput dari nilai nilai estetis, dengan warna dan komposisi yang rendah bahkan ada pula meme yang cenderung dipaksakan. (Alimecca,2014)
Sebagai fenomena di jagat maya, meme mendapat respon hangat dari warganet. Kontennya menghibur dan mengandung parodi. Tak jarang pula meme juga memancing masalah baru terutama pada pihak yang merasa tersindir sehingga mereka pun membalas dengan membuat meme balasan. Kondisi ini membuat sebagian warganet tidak lagi bisa berpikir rasional dan menjadikan segala sesuatu sebagai bahan candaan.

Salah satu yang sering menjadi sasaran para creator meme adalah Gubernur DKI Jakarta Anies Bawesdan. Anies kerap menjadi target para pembuat meme untuk ramairamai menyudutkan berbagai kebijakan pemerintah DKI Jakarta yang dianggap tidak berguna, dan tidak mewakili aspirasi warga Jakarta. Seperti yang belum lama ini terjadi adalah fenomena banjir Jakarta di awal tahun 2020. Para creator meme tersebut menyudutkan Anies Bawesdan secara membabi buta mengkritik ketidak becusan Gubernur Anies Bawesdan dalam mengatasi permasalahan banjir di Jakarta. Kondisi inilah yang membuat ramai-ramai warganet membully Gubernur Anies Bawesdan sehingga melahirkan tagar \#BanjirJakarta \#Banjir \#BanjirJakarta4niesDimana yang menjadi trending topic di jagat twitter nasional. Melalui tagar tersebut para creator meme beramai-ramai mengekspresikan kekesalannya terhadap masalah banjir Jakarta yang tidak pernah tuntas malah semakin bertambah parah sejak era Gubernur Anies Bawesdan.

Padahal saat masa kampanye dulu, Anies dengan janji manisnya yakin bisa menuntaskan masalah banjir Jakarta. Bahkan dia saat itu meyakini bahwa solusi untuk mengatasi banjir Jakarta adalah dengan mengalirkan air ke dalam bumi 
(tanah) bukan dialirkan ke laut. Hal ini pula yang membuat warganet menjadi gemas dan ramai-ramai mengekspresikan kekesalahnya lewat meme untuk mencibir Gubernur Anies Bawesdan melalui tagar \#BanjirJakarta \#Banjir \#BanjirJakarta4niesDimana.

Kegemasan warganet makin menjadi karena dalam dua tahun masa kepemimpinannya tidak satupun ada gebrakan yang dilakukan Gubernur Anies Bawesdan dalam mengatasi banjir Jakarta. Jangankan untuk melakukan normalisasi aliran sungai seperti yang sudah dilakukan oleh gubernur sebelumnya, Gubernur Anies Bawesdan malah memotong separuh anggaran penganggulangan banjir. Gubernur Anies malah bersilat lidah dan menyebut akan membangun drainase vertikal yang masuk ke tanah.

Berangkat dari kasus tersebut maka fenomena meme menjadi menarik untuk diteliti. Adapun rumusan masalah dalam penelitian ini adalah mencari unsur-unsur semiotika yang terdapat dalam meme banjir Jakarta Gubernur Anies Bawesdan yang banyak digunakan oleh warganet dalam menyampaikan aspirasi, dan kritik. Dengan menemukan unsur semiotika tersebut kita bisa mendapatkan makna dan tujuan sang kretor meme saaat memproduksi meme tersebut di media sosial termasuk mencari tanda-tanda dan ungkapan-ungkapan yang digunakan kreator dalam membuat meme tersebut. Selanjutnya, penelitian ini diharapkan bisa menambah khasanah baru bagi ilmu pengetahuan terutama bidang komunikasi dalam memahami produk budaya baru berupa meme dari para kreatornya di media sosial.

\section{METODOLOGI PENELITIAN}

Analisis semiotika Charles Sanders Pierce digunakan untuk menguraikan berbagai tanda-tanda, symbol dan penafsiran yang digunakan oleh kreator saat menciptakan meme tesebut. Penggunaan analisis semiotik dilakukan untuk membongkar berbagai makna tanda, symbol dan penafsiran para berbagai narasi sebagai teks dan foto sebagai lambang pesan. (Pawito,2007 : 155). Untuk dapat menguraikan makna dalam meme yang dibuat para kreator tersebut maka ada tiga unsur yang akan dianalisis yaitu tanda, obyek dan penafsir.

Tanda dalam analisis semiotika Pierce dapat mewakili suatu gagasan, ekspresi atau perasaan dari sang kreator. Tanda tersebut bekerja menjadi suatu tindakan, sehingga menimbulkan pengaruh atau influence yang saling berkaitan saatu sama lain sehingga dengan dmikian tanda (sign), obyek (object) akan menghasilkan penafsiran (interpretan) dari sang pembuatnya.

Tanda juga digunakan untuk menguraikan makna dari meme tersebut. Tanda itu berbentuk fisik yang dapat dilihat secara kasat mata. Biasanya merepresentasikan halhal tertentu dari meme tersebut. Pierace menyebut baahwa ada tiga tanda yang dapat diungkap yaitu symbol, ikon, dan indeks. Simbil biasanya berupa tanda kesepakatan, ikon adalah tanda fisik sedangkan indeks merupakan hubungan sebab akibat.Sementara obyek bisa merupakan referensi atau acuan tanda yang dibuat oleh kreator tersebut. Kemudian interpretan menjaadi sarana interpretasi ataau pemikiran yang muncul dari sang kreator. Interpretan ini dapat menjadi penafsiran baru dari sang kreator saat membuat meme tersebut.

Untuk dapat menemukan berbagai tanda,symbol dan ikon tersebut maka peneliti akan membongkar berbagai gambar, foto dan narasi yang ada pada meme banjir Jakarta Gubernur Anies Bawesdadn. Memememe tersebut dapat terungkap makannya 
dengan perumusana berbagai macam tanda yang ada dalam analisis Semiotika ini.

Dalam menungkap berbagai tanda semiotika tersebut, peneliti mengumpulkan sejumlah meme Gubernur Anies Bawesdan yang muncul pada hastag (\#)BanjirJakarta, (\#)Banjir dan (\#)BanjirJakarta4niesDimana sejak tanggal 1 Januari 2020. Dari hasil pemilihan tersebut terdapat 5 meme yang paling hits di twitter untuk diteliti.

\section{HASIL DAN PEMBAHASAN}

Selama dua hari Jakarta diguyur hujan, membuat berbagai wilayah di Jabodetabek terendam banjir. Kondisi banjir awal tahun 2020 ini diklaim sebagai yang terparah sejak tahun 2015. Alhasil Gubernur DKI Jakarta Anies Bawesdan menjadi target sasaran kekesalan warganet yang dianggap tidak becus dalam menangani masalah banjir Jakarta. Seperti apa meme-meme banjir Jakarta untuk Anies Bawesdan? Berikut penjelasannya.

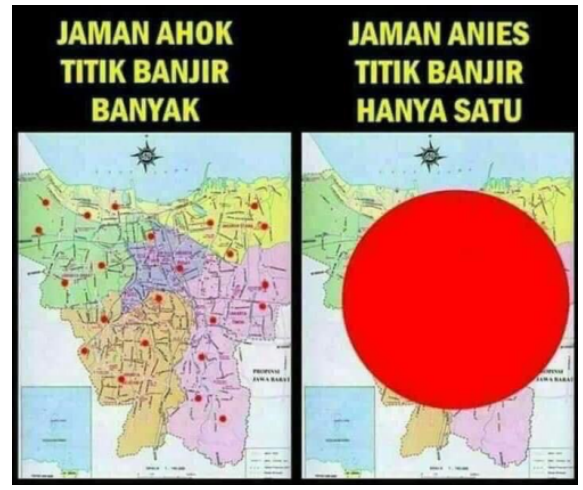

Gambar 1. Meme membandingkan titik banjir di jaman Ahok dengan Jaman Anies.

Berdasarkan elemen tanda dari Pierce bisa terlihat bahwa meme tersebut berusaha membandingkan antara dua jaman yaitu Ahok dan Anies dalam menangani berbagai titik banjir yang berada di Jabodetabek.
Meme tersebut menampilkan peta lanskap Propinsi DKI Jakarta lengkap dengan berbagai titik merah yang menjadi symbol dari daerah yang menjadi langganan banjir. Pada gambar sebelah kiri yaitu di jamannya Ahok terlihat bahwa titik banjir di Jakarta tersebar dengan jelas dan mengecil. Sedangkan di jaman Anies, lokasi titik banjir itu tidak tampak menyebar melainkan memusat namun titik merahnya sangat besar. Ini menandakan bahwa era Anies itu banjirnya lebih parah daripada eranya Ahok. Dengan penggunaan perbandingan peta banjir antara jaman Ahok dan jaman Anies, warganet semakin paham era siapa yang sebenarnya lebih baik dalam mengatasi banjir Jakarta. Penggunaan peta dimaksudkan agar warganet tidak kesulitan dalam mencerna makna dari meme tersebut.

Kemudian berdasarkan elemen obyek yang menjadi konteks dari meme ini dibuat adalah pada gambar sebelah kiri, sang creator hendak menjelaskan bahwa penanganan banjir di Jakarta di era Ahok itu lebih terlihat dan punya strategi penanganannya. Ahok banyak melakukan normalisasi aliran sungai, menertibkan daerah sekitar sungai agar bersih dari tempat tinggal warga, dan berbagai program llainnya. Akibatnya di jaman Ahok itu titik banjir banyak namun kecil-kecil yang diartikan bahwa titik banjirnya sudah tidak sebanyak dulu dan jikapun tergenang bisa dipastikan akan cepat surut.

Kondisi berbeda di jaman Anies dimana titik banjir hanya satu namun sangat besar. Ini menjadi symbol bahwa era Anies kondisi banjir Jakarta sangat parah karena Anies tidak punya program konkrit untuk mengurangi banjir di Jakarta. Selama dua tahun kepemimpinannya sebagai Gubernur DKI Jakarta Anies Bawesdan tidak punya gebrakan apapun dalam mengatasi masalah banjir di Jakarta. 
Sedangkan dari sisi interpretant atau penafsir bisa dibilang sang creator hendak menyampaikan makna bahwa era Ahok lebih baik daripada jaman Anies dalam masalah penanganan banjir. Bahkan di dalam meme perbandingan tersebut sang creator ingin menunjukan bahwa era Anies lebih parah dalam urusan menangani masalah banjir. Ini terlihat dari besarnya titik merah yang hampir menutupi semua wilayah Jakarta yang luas. Warna merah juga menjadi lambang kewaspadaan bahwa era Anies tidak pernah serius dalam mengatasi masalah banjir. Dan akhirnya terbukti bahwa banjir di awal 2020 menjadi musibah yang paling parah. Daerah yang sebelumnya tidak pernah terkena banjir, mendadak ikut kebanjiran. Hal inilah yang membuat ribuan warga Jakarta mengungsi ke berbagai tempat. Warga pun harus merelakan rumah dan harta bendanya terendam banjir.

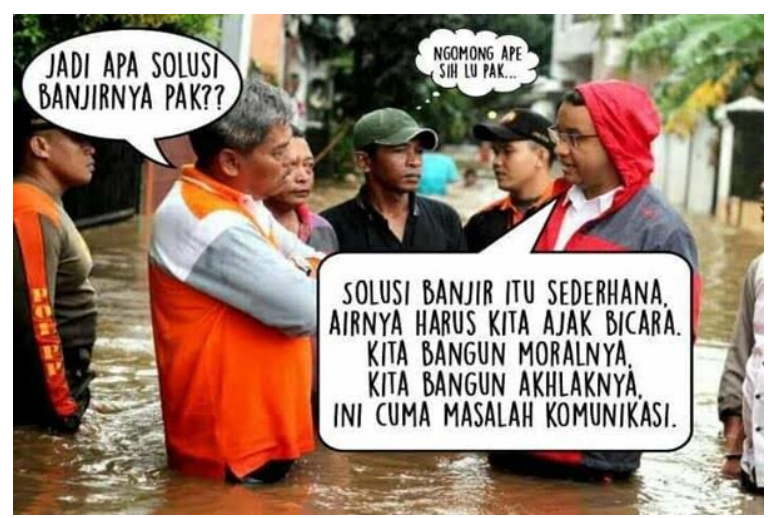

\section{Gambar 2. Meme dialog warga dengan Gubernur Anies Bawesdan.}

Sesuai dengan elemen tanda dari Pierce meme diatas dibuat dengan menggunakan foto saat Gubernur Anies Bawesdan mengunjungi salah satu daerah yang terkena banjir. Dalam foto tersebut sang creator menyelipkan dialog imajiner yang seolaholah terjadi antara Anies dengan warga sekitar. Dialog dalam foto tersebut adalah sebagai berikut

Warga: Jadi apa solusi banjirnya pak? Anies : Solusi banjir itu sederhana, airnya harus kita ajak bicara. Kita bangun moralnya, kita bangun akhlaknya, ini cuma masalah komunikasi.

Warga : Ngomong ape sih lu pak....

Saat terjadi dialog dalam foto itu terlihat ekspresi warga yang serius menyimak penjelasan Anies. Sementara warga yang lain seperti sedang menahan kesal karena tempat tinggalnya terendam banjir hingga sepaha orang dewasa.

Sedangkan elemen objek dalam meme ini terlihat bahwa ada 3 orang warga yang terlihat serius mendengar penjelasan Gubernur Anies Bawesdan yang didampingi oleh dua orang stafnya. Dialog dengan warga tersebut dilakukan di tengah banjir. Dalam foto itu terlihat bahwa Anies berusaha untuk memberikan penjelasan yang bisa diterima warganya tersebut.

Adapun untuk interpretant dari meme itu bahwa creator ingin menunjukan kepada warganet Gubernur Anies Bawesdan sama sekali tidak punya program kongkrit untuk mengatasi banjir. Hal ini terlihat dari dialog antara Anies dengan warganya tersebut. Warga sebenarnya ingin mendengar langsung apakah memang sang gubernur punya solusi kongkrit untuk mengatasi banjir di Jakarta? Dan jawabannya Anies tidak punya program untuk atasi Jakarta. Anies lebih cenderung bermain dengan retorika yang menjadi andalannya tersebut. Lewat retorika yang disusun dengan tata bahasa yang halus dan sopan, Anies berusaha mengambil simpati dari warga yang terkena banjir tersebut. Hanya sayangnya, cara tersebut tidak terlalu 
berpengaruh terhadap warga yang sedang kena musibah banjir tersebut.

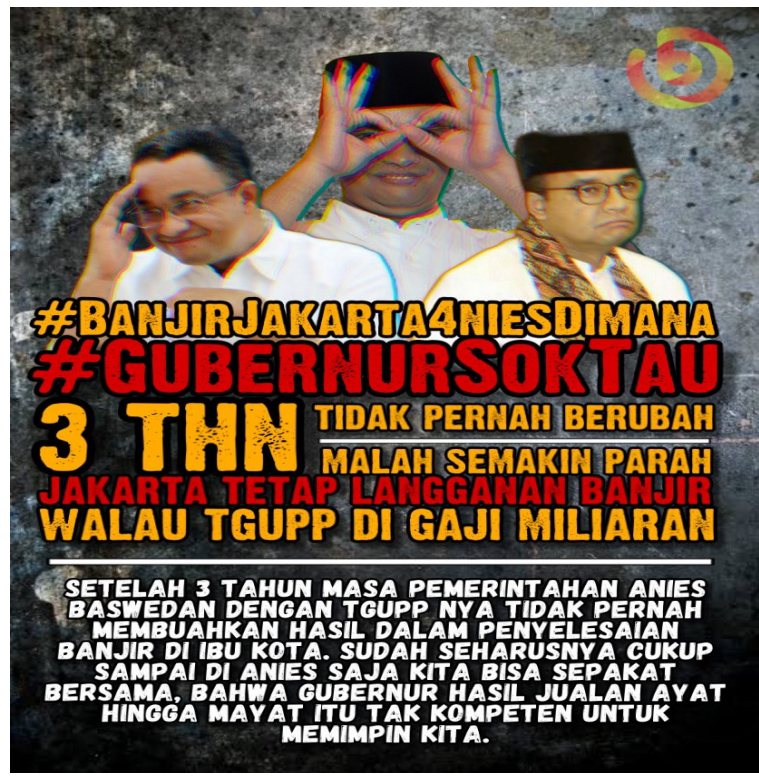

Gambar 3. Meme

\#BanjirJakarta4niesDimana

Pada gambar ketiga terlihat bahwa elemen tanda penyusun meme tersebut adalah berbagai ekspresi Gubernur Anies Bawesdan pada suatu kesempatan. Sang pembuat meme mengambil tiga ekspresi Anies yang kemudian dibuat menjadi foto kolase. Meme ini semakin satire karena berisi pernnyataan dari pembuat meme mengenai ketidakbecusan Gubernur Anies Bawesdan dalam menjalankan roda pemerintahan di kota Jakarta selama tiga tahun. Sang pembuat menumpahkan kekesalannya terhadapAnies dengan menyebut Jakarta tetap saja menjadi langganan banjir walau TGUPP digaji miliaran rupiah. Bahkan TGUPP itu sama sekali tidak punya hasil yang kongrit. Meme berisi konten pernyataan yang sangat provokatif dan cenderung menyerang kinerja Anies yang tidak becus dalam menata kota Jakarta.
Sedangkan yang menjadi elemen obyek dalam meme tersebut adalah ekspresi Gubernur Anies Bawesdan yang ditampilkan secara berbeda-beda. Pada meme tersebut sang kreator memilih tiga ekspresi khusus Anies dari sekian banyak pilihan ekspresi saat menjadi Gubernur DKI Jakarta. Anies sebagai obyek dalam meme tersebut terlihat sangat menonjol dan mendominasi. Ketiga ekspresi Anies itu ditampilkan secara kontras dengan latar belakang meme warna hitam. Menariknya dalam meme ini, sang creator membuat pernyataan yang menunjukan nada kekesalan saat Jakarta dipimpin oleh Gubernur Anies Bawesdan.

Kemudian untuk sisi interpreter atau penafsir, sang creator ingin menunjukan bahwa Gubernur Anies Bawesdan ini adalah orang yang tidak bisa bekerja. Alihalih ingin membuat Jakarta lebih baik yang terjadi malah sebaliknya, semakin amburadul. Selama tiga tahun kepemimpinan Anies tidak ada satu pun perubahan berarti yang dilakukan Anies sehingga membuat kehidupan warganya menjadi lebih nyaman dan tentram.

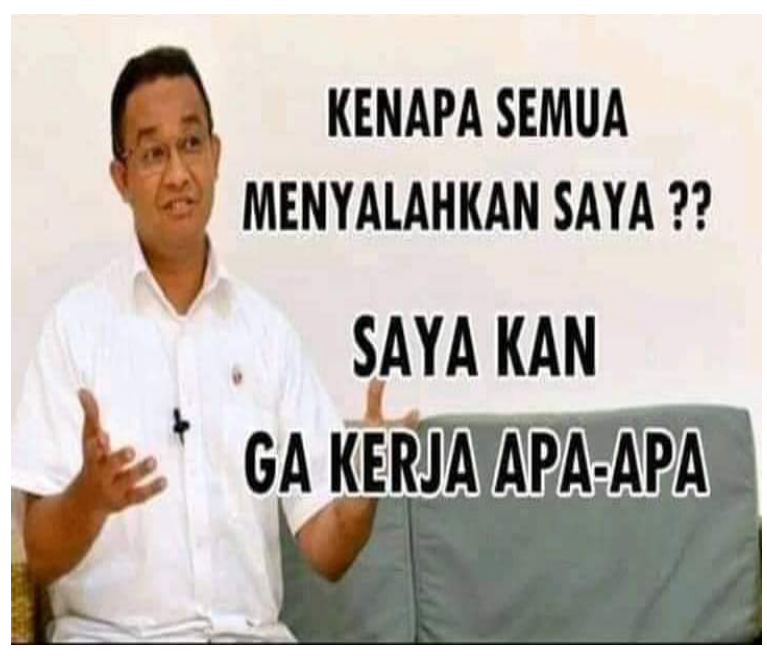

Gambar 4 Meme Kenapasemua menyalahkann saya? 
Elemen tanda yang terlihat pada gambar keempat ini adalah foto Gubernur Anies dalam ekpresi yang berusaha menjelaskan sesuatu. Foto Anies ditampilkan seorang diri dengan tangan terbuka seolah hendak menjelaskan sesuatu. Oleh sang creator foto tersebut dibikin menjadi dialog imajiner yang berbunyi : Kenapa semua menyalahkan saya? Saya kan gak kerja apa apa?

Adapun elemen objek yang ada dalam meme tersebut adalah foto Anies seorang diri yang sedang duduk di atas sofa. Foto itu sengaja dipilih oleh sang creator karena ekspresinya sesuai dengan dialog imajiner yang ditammpilkan dalam meme tersebut. Sedangkan sisi interpreter atau penafsir, sang creator ingin menunjukan bahwa Anies seolah lepas tangan. Dia tidak mau begitu saja jadi target sasaran warganet karena tidak becus dalam mengatasi masalah banjir. Tentu saja meme ini bisa memancing kekesalan para warganet karena Gubernur Anies sama sekali tidak punya solusi atas masalah banjir di Jakarta

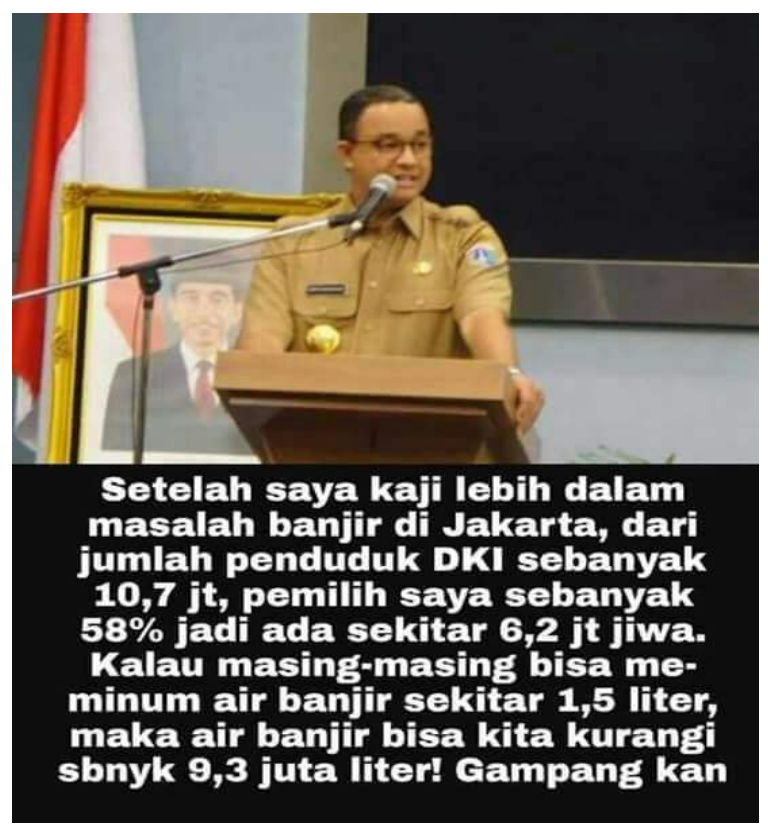

Gambar 5. Meme Anies Sedang berpidato
Unsur tanda yang terlihat pada gambar kelima ini adalah sosok Gubernur Anies Bawesdan yang tampil sedang berpidato. Sang creator memasang foto tunggal gubernur dengan menambahkan ilustrasi pernyataan di bawah foto tersebut. Pernyataan tersebut berbunyi : Setelah saya kaji lebih dalam masalah banjir di Jakarta, dari jumlah penduduk DKI sebanyak 10,7 juta, pemilih saya sebanyak 58 persen jadi ada sekitar 6,2 juta jiwa.Kalau masingmasing bisa meminum air banjir sekitar 1,5 liter maka air banjirbisa kita kurangi sebanyak 9,3 juta liter! Gampang kan

Dari elemen tanda tersebut Gubernnur Anies ditampilkan sebagai sosok yang santun dalam bertutur kata dan pintar beretorika. Namun sejatinya kosong dalam program terutama mengatasi masalah banjir. Adapun untuk elemen objek pada meme tersebut adalah Gubernur Anies Bawesdan yang ditampilkan sebagai sosok tunggal yang mengisyaratkan bahwa dialah penguasa Jakarta. Bahkan foto Presiden Jokowi yang harusnya ditempatkan lebih tinggi ternyata posisinya ditaruh di belakang Anies.

Sedangkan sisi interpreter atau penafsir, bisa dibilang meme ini menyindir Anies yang terkenal jago beretorika dengan tata bahasa yang manis namun sejatinya Anies tidak paham bagaimana mengatasi banjir di Jakarta. Lewat dialog imajiiner yang diperlihatkan oleh sang creator, Anies cenderung menyederhanakan permasalahan banjir sebagai solusi yang udah. Padahal untuk mengatas banjir tersebut butuh penanganan komprehensif yang menyeluruh. Tidak bisa dilakukan secara parsial.

Dari berbagai temuan berdasarkan analisa semiotika tersebut terlihat bahwa hasilpenelitian ini menunjukan bahwa meme-meme tentang Gubernur Jakarta 
Anies Bawesdan yang muncul pada \#BanjirJakarta \#BanjirJakarta4niesDimana \#Banjir adalah bernada satire yang cenderung menyindir dan menyerang kebijakan Anies yang tidak melakukan apapun dalam mengatasi masalah banjir di Jakarta. Hal ini lah yang lantas memicu gelombang warganet untuk membully Anies di media sosial terutama twitter.

Meme bernada satire tersebut bernada ironi yang dikemas dalam balutan humor atau guyonan. Lewat meme satire tersesbut maka tokoh yang menjadi target sasaran diekspose kesalahannya lalu diamplifikasi sebanyak-banyaknya dengan membuat meme yang beragam. Satire sendiri berfungsi untuk menyampaikan kritik terutama untuk penguasa (Berger, 1997). Meme satire banyak dipilih oleh creator untuk menyampaikan kritik dengan cara yang ringan dan menimbulkan tawa kepada yang membacanya. Selain itu dengan cara satire tersebut diharapkan makna dari meme tersebut bisa tersampaikan dengan baik sehingga menimbulkan pemahaman yang sama. Tidak multitafsir.

Kehadiran meme satire ini seolah menjungkir balikan norma kesopanan dengan segala etikanya. Dalam jurnal Wadipalapa (2015) tentang "Meme Culture dan Komedi Satire Politik: Kontestasi Pemilihan Presiden dalam Media Baru" disebutkan bahwa norma kesopanan menghilang berganti dengan komedi ironi dengan pesan bermuatan satir tajam. Kehadiran meme humor yang muncul pada berbagai ranah politik menjadi tanda bahwa massyarakat sudah semakin kritis dengan tema-tema politik yang bermunculan.

Dalam meme banjir Jakarta Gubernur Anies Baswedan ada hal yang menarik yaitu pesan komedi yang terungkap dalam meme tersebut. Teori komedi menyebut bahwa ada dua unsur humor yang bisa dicatat pertama adalah unsur superioritas sebagai posisi yang mentertawakan dan inferioritas dalam posisi ditertawakan. Menariknya, baik superioritas maupun inferioritas adalah dua peristiwa atau situasi yang mustahil terjadi sekaligus. (Wadipalapa, 2015).

Kaitannya dengan meme Anies Bawesdan ini adalah yang menjadi pihak superior adalah para creator meme dan warganet yang menikmati meme tersebut. Sedangkan Anies menjadi sosok yang inferior.

Bagi warganet yang merasa sepemahaman dengan meme tersebut tentu akan bergabung dalam satu barisan untuk ikut membuat meme serupa untuk mengekspresikan pendapat dan gagasan mereka tentang kebijakan Anies Bawesdan dalam mengatasi banjir Jakarta. Sedangkan bagi warganet yang tidak sepemahaman tentu akan membuat meme tandingan atau counter attack teerhadap memeyang sudah beredar tersebut. Tak jarang dari aktivitas tersebut sering menimbilkan perang di dunia medsos atau disebut dengan twitwarr.

\section{KESIMPULAN}

Berdasarkan unsur semiotika pada meme Gubernur Anies Bawesdan tampil dengan beragam bentuk. Meski demikian para creator cenderung menggunakan foto ekspresi Anies dalam pembuatan meme tersebut. Tentunya ekspresi Anies dipilih sesuai dengan isi pesan yang ingin disampaikan dalam bahasa satire.

Bentuk meme ini hampir sama karena disertai dengan beragam komentar humor satire di dalamnya. Meme yang ditampilkan tersebut punya tone yang sama berupa sindiran dan ketidaksukaan warganet terhadap Gubernur Anies Bawesdan yang tidak becus dalam menata kota Jakarta. Baik sikap maupun pandangan dari warganet 
cenderung sama dengan gagasan tang hendak disampaikan oleh kreator meme tersebut. Lewat meme tersebut mereka pun seolah bersatu menyindir Anies Bawesdan.

\section{DAFTAR PUSTAKA}

Alimecca. 2014. Geliat Visual Meme di Ranah Media Sosial- Indonesia Kreatif News Blog.

http://news.indonesiakreatif.net/geliatvisual-meme/

Amretasari, D Vermita. 2014. Struktur Teks Bergambar Meme Keanu Conspiration dalam Media Sosial. Skripsi Universitas Gadjah Mada Yogyakarta

Berger, Peter. L. (2014). Redeeming laughter: Comic dimension of human experience. Berlin : Walter de Gruyter GmbH \& Co KG.

Dawkins, Robert. (1976). The selfish gene. New York, NY: Oxford University Press.

Juditha, C. 2015. "Fenomena Trending Topic Twitter: Analisis Wacana Twit\# SaveHajiLulung." Jurnal Penelitian Kominfo Jakarta.

Peirce, Charles S. 1982. "Logic as Semiotics: The Theory of Sign" Bloomington: Indiana Universty Press.

Ramadhana, Tiara S. 2015. Kecenderungan Cara Penyampaian Pesan dalam Internet Meme (Analisis Isi Internet Meme dalam Akun Dagelan di Instagram, periode 01-31 Januari 2015). Skripsi Universitas Muhammadiyah Malang.

Sobur, Alex. 2013. Semiotika Komunikasi. Bandung: PT. Remaja Rosdakarya
Wadipalapa, Rendy P. 2015. Meme Culture \& Komedi Satire : Kontestasi Pemilihan Presiden dalaam Media Baru. Jurnal Penelitian. Universitas Airlangga. 